\title{
Analisis dampak perubahan iklim terhadap produksi kedelai dan pilihan adaptasi strategisnya pada lahan tadah hujan di kabupaten Garut
}

Sari Perubahan iklim dapat menimbulkan ancaman bagi kegiatan pertanian karena berdampak terhadap kenaikan frekuensi dan intensitas kejadian cuaca ekstrem, perubahan pola hujan, serta peningkatan suhu udara dan kenaikan permukaan air laut. Tanaman kedelai merupakan komoditas yang paling sensitif terhadap perubahan iklim karena memiliki dampak penurunan produksi yang tinggi. Maka dari itu telah dilakukan analisis perubahan iklim terhadap produksi tanaman kedelai di wilayah Kabupaten Garut, Jawa Barat. Penelitian ini bertujuan untuk mengidentifikasi adanya perubahan iklim di Kabupaten Garut, mengetahui dampak perubahan unsur iklim yaitu suhu udara dan curah hujan terhadap produksi dan produktivitas kedelai serta mengidentifikasi usaha adaptasi yang dilakukan oleh para petani. Metode yang digunakan dalam penelitian adalah deskriptif kuantitatif. Hasil penelitian menunjukkan bahwa telah terjadi perubahan iklim di wilayah Kabupaten Garut. Dampak perubahan iklim terhadap penurunan produksi kedelai berkorelasi signifikan. Penurunan produksi kedelai di Kabupaten Garut disebabkan oleh faktor perubahan curah hujan dan suhu udara. Adaptasi yang harus dilakukan petani adalah dengan menanam bibit kedelai yang mampu beradaptasi dengan perubahan iklim, melakukan pengaturan pola tanam, dan membuat sumur resapan air.

Kata kunci: Perubahan iklim · Produksi kedelai · Dampak · Adaptasi strategis

\section{Analysis the impact of climate change on soybean production and identify strategic adaptation on rainfed in Garut district}

\begin{abstract}
Climate change can cause a threat for agriculture because it affects to the increased frequency and intensity of extreme weather, changes in rainfall patterns, and increase in global temperature also sea level rise. Soybean is the most sensitive commodity to climate change because it has a high impact of reduced production. Therefore it has been studied the impact of climate change on the production of soybean in the area of Garut District, West Java. The research object was to identify climate change in Garut District, determine the impact of climate change which is air temperature and rainfall on the production and productivity of soybean and identify adaptation efforts should be done by farmers. The method used in this research is quantitative descriptive. The results showed that the area of Garut District has experienced climate change. The climate change was significant affected on the decreased of soybean production. The decreased of soybean production in Garut District was caused by changes in rainfall and air temperature. Adaptation that must be done by the farmers are planting of yield that be able to adapt to climate change, regulate cropping patterns, and make infiltration wells.
\end{abstract}

Keywords: Climate change · Soybean production · Impacts • Adaptation strategic

Diterima : 17 Juni 2020, Disetujui : 31 Juli 2020, Dipublikasikan : 12 Agustus 2020 doi: https://doi.org/10.24198/kultivasi.v19i2.27998

\footnotetext{
Ruminta · A.W. Irwan · T. Nurmala · G. Ramadayanty

Departemen Budidaya Pertanian, Prodi Agroteknologi, Fakultas Pertanian Unpad

Korespondensi: ruminta@unpad.ac.id
} 


\section{Pendahuluan}

Perubahan iklim merupakan perubahan secara alamiah atau dipengaruhi oleh aktivitas manusia yang dapat mengubah komposisi atmosfer dan memperbesar keragaman iklim pada periode yang cukup panjang (Handoko et al., 2008). Perubahan iklim dapat berpengaruh pada sistem pertanian, karena berdampak terhadap kenaikan frekuensi dan intensitas kejadian cuaca ekstrem, perubahan pola hujan, serta peningkatan suhu dan kenaikan permukaan air laut. Penelitian Runtuwu dan Kondoh (2008) menunjukkan telah terjadi peningkatan suhu udara global selama seratus tahun terakhir, dengan rata-rata 0,57 ${ }^{\circ} \mathrm{C}$. Perubahan iklim mengakibatkan keragaman iklim semakin besar yang terlihat dari makin cepatnya periode El Nino di Indonesia yang semula terjadi dalam 5-6 tahun sekali, menjadi 2-3 tahun sekali (Mantom et al., 2001).

Salah satu tanaman yang peka terhadap perubahan iklim ialah tanaman kedelai. Kedelai (Glycine max L.) adalah salah satu tanaman polong-polongan dan merupakan sumber utama protein dan minyak nabati di dunia. Namun, produksi kedelai di dalam negeri hanya mampu memenuhi sekitar $40 \%$ kebutuhan domestik dan sisanya sekitar $60 \%$ dipenuhi dari kedelai impor (Carolina, 2016). Adanya penurunan luas panen kedelai yang tak seimbang dengan peningkatan produktivitas menyebabkan ketidakstabilan pada produksi kedelai di Indonesia (Malian, 2004). Selain itu adanya pengaruh perubahan iklim menjadi salah satu faktor yang sulit dikontrol dan berdampak terhadap perubahan produksi kedelai. Apriyana et al. (2016) menuturkan bahwa perubahan iklim di kawasan Asia Tenggara dapat menurunkan produksi tanaman kedelai sebesar 12,4\%. Menurut penelitian Agung (2016) di Maluku, kedelai merupakan komoditas yang paling sensitif terhadap perubahan iklim karena memiliki dampak penurunan produksi ketika kondisi El Nino sebesar 10,7\% maupun La Nina sebesar 11,4\%. Handoko et al. (2008) menuturkan bahwa penurunan curah hujan sebesar $246 \mathrm{~mm} /$ tahun diperkirakan akan menurunkan produksi kedelai hingga 65,2\%. Menurut Putra dan Indradewa (2011) peningkatan suhu udara sebesar $5^{\circ} \mathrm{C}$ akan menurunkan produksi kedelai sebesar $10-30 \%$.
Perubahan iklim dapat mengancam produksi tanaman kedelai di Kabupaten Garut, Jawa Barat. Kabupaten Garut merupakan salah satu sentra produksi kedelai di Jawa Barat. Program swasembada kedelai pun menjadi target agar tidak terjadi ketergantungan terhadap kedelai impor yang semakin besar. Diketahui hasil produksi tanaman kedelai di Kabupaten Garut mencapai 21.434 ton dengan luas panen sebesar 25.939 ha (Badan Pusat Statistik, 2015). Begitu pula dengan produktivitasnya yang cukup tinggi mencapai 17.08 kuintal/ha (Dinas Tanaman Pangan dan Hortikultura Kabupaten Garut, 2018). Dengan jumlah produksi tersebut, Kabupaten Garut mampu memenuhi kebutuhan kedelai di daerahnya dan membantu menyuplai kedelai di daerah lain yang ada di Jawa Barat. Sebesar $16,14 \%$ luas lahan di Kabupaten Garut merupakan lahan persawahan yang terbagi menjadi lahan irigasi seluas 38.026 ha dan lahan tadah hujan seluas 11.451 ha. Kedelai ditanam pada awal musim hujan dan musim kemarau I pada lahan kering dan pada lahan sawah kedelai ditanam pada musim kemarau I jika ketersediaan air tidak mencukupi bagi penanaman padi (Adinasa et al., 2015). Kedelai ditanam pada lahan tadah hujan dan pada lahan kering (di lahan tegalan), dimana tanaman kedelai diusahakan pada musim hujan saja sehingga ketersediaan air sangat dipengaruhi oleh curah hujan.

Namun, dalam 15 tahun terakhir trend produksi kedelai mengalami fluktuasi yang cukup tajam. Hal tersebut disebabkan oleh keterbatasan lahan untuk pertanaman kedelai serta diduga adanya faktor perubahan iklim dimana sebagian tanaman kedelai ditanam di lahan tegalan dan sawah tadah hujan, sehingga ketersediaan air sangat dipengaruhi oleh curah hujan. Terkait dengan hal tersebut, penelitian perlu dilakukan untuk mengetahui seberapa besar perubahan iklim yang terjadi di Kabupaten Garut dari tahun 1982-2018, bagaimana hubungan antara perubahan iklim dengan perubahan produksi dan produktivitas, dan mengetahui pilihan adaptasi strategis untuk mengatasi penurunan produksi kedelai di Kabupaten Garut, Jawa Barat. Tujuan dari penelitian ini yaitu mengkaji seberapa besar terjadinya perubahan iklim dan mengetahui dampak perubahan unsur iklim, yaitu suhu udara dan curah hujan, terhadap produksi dan 
produktivitas kedelai serta mengidentifikasi usaha adaptasi yang dilakukan oleh para petani.

\section{Bahan dan Metode}

Penelitian dilaksanakan pada tahun bulan November-Maret 2020. Penelitian ini menggunakan metode deskriptif kuantitatif. Penelitian ini menggunakan data historis dan data hasil observasi langsung yang berupa data iklim dan data tanaman kedelai meliputi data produksi, produktivitas, luas tanam, dan luas panen kedelai di Kabupaten Garut yang masingmasing diambil dari tahun 1982 hingga tahun 2018. Data iklim diperoleh dari Stasiun Cuaca Pameungpeuk Garut sedangkan data pertanian tanaman kedelai diperoleh dari Dinas Pertanian dan BPS Kabupaten Garut.

Analisis data penelitian menggunakan analisis trend, korelasi dan proyeksi seperti berikut :

(a). Analisis garis trend (regresi) menggunakan persamaan berikut.

$$
\begin{aligned}
& Y=b_{0}+b_{1} X \\
& b_{0}=\frac{\left(\sum_{i=1}^{n} y_{i}\right)}{n} \\
& b_{1}=\frac{\sum_{i=1}^{n}\left(x_{i} y_{i}\right)}{\sum_{i=1}^{n}\left(x_{i}\right)^{2}}
\end{aligned}
$$

di mana : $Y=$ nilai trend data iklim (curah hujan, suhu, atau radiasi matahari) atau data tanaman kedelai (data luas tanam, produktivitas, atau produksi); $\quad \mathrm{b}_{0}=$ nilai konstanta yaitu nilai $\mathrm{Y}$ pada saat nilai $X=0 ; b_{1}=$ nilai kemiringan garis, yaitu tambahan nilai $Y$, apabila $X$ bertambah satu satuan; dan $X=$ periode tahun.

(b). Analisis hubungan antara perubahan iklim dengan perubahan produksi kedelai menggunakan rumus korelasi berikut:

$$
r=\frac{\sum_{i=1}^{n} x_{i} y_{i}-\frac{1}{n}\left(\sum_{i=1}^{\mathrm{n}} x_{i}\right)\left(\sum_{i=1}^{\mathrm{n}} y_{i}\right)}{\sqrt{\left(\sum_{i=1}^{n}\left(x_{i}\right)^{2}-\frac{1}{n}\left(\sum_{i=1}^{\mathrm{n}} x_{i}\right)^{2}\right)\left(\sum_{i=1}^{n}\left(y_{i}\right)^{2}-\frac{1}{n}\left(\sum_{i=1}^{\mathrm{n}} y_{i}\right)^{2}\right)}}
$$

dimana: $r=$ koefisien korelasi; $X_{i}=$ data curah hujan, suhu, atau radiasi matahari; dan $Y_{i}=$ data luas tanam, produktivitas, atau produksi kedelai.

(c). Proyeksi perubahan produksi kedelai akibat perubahan iklim menggunakan persamaan regresi berganda yaitu (Montgomery \& Peck, 1992):

$$
y=b_{0}+b_{1} x_{1}+b_{2} x_{2}+b_{3} x_{3}+b_{4} x_{4}+b_{5} x_{5}
$$

dimana: $y=$ produksi kedelai, $x_{1}=$ data curah hujan, $x_{2}=$ data suhu udara, $x_{3}=$ data radiasi matahari, $x_{4}=$ data luas tanam kedelai, $x_{5}=$ data produkstivitas kedelai, dan $b_{0}, b_{2}, \ldots . ., b_{5}=$ parameter regresi.

Penelitian ini juga melakukan survai terhadap petani kedelai dan petugas penyuluh pertanian untuk mengetahui pilihan adaptasi perubahan iklim yang telah dilakukan oleh petani kedelai di Kabupaten Garut. Analisis dan interpretasi data penelitian menggunakan Software Minitab 16 dan Microsoft Excel 2013.

\section{Hasil dan Pembahasan}

Deskripsi Produksi Kedelai di Kabupaten Garut. Kedelai merupakan tanaman yang masuk ke dalam tanaman pangan utama. Selain sebagai sumber protein, kedelai juga digunakan sebagai bahan baku industri ternak. Di Kabupaten Garut sendiri, penggunaan kedelai tertinggi mencapai 10.082 ton untuk industri tahu dan tempe (Dinas Perindustrian Kabupaten Garut, 2012). Perkembangan produksi kedelai pada tahun 1982-2018 di Kabupaten Garut dapat dilihat pada Gambar 1. Terlihat perkembangan kedelai yang fluktuatif di Kabupaten Garut selama 37 tahun terakhir ini (1982-2018). Menurut Hadi (2013), laju pertumbuhan kedelai domestik pada tahun 1991-2000 dan tahun 2001-2011 telah mengalami penurunan sebesar $-2,94 \%$ dan $5,27 \%$. Penurunan produksi tersebut disebabkan karena adanya penurunan dari luas panen kedelai di Kabupaten Garut.

Analisis Perubahan Iklim di Kabupaten Garut. Berdasarkan analisis data suhu udara dan curah hujan selama 37 tahun (1982-2018) wilayah Kabupaten Garut telah mengalami perubahan iklim yang tertera pada Tabel 1 berikut. 
Tabel 1. Perubahan iklim di kabupaten Garut.

\begin{tabular}{lcc}
\hline \multicolumn{1}{c}{ Indikator Iklim } & \multicolumn{2}{c}{ Perubahan Iklim } \\
\cline { 2 - 3 } & $\begin{array}{c}\text { Tahun } \\
1982-2000\end{array}$ & $\begin{array}{c}\text { Tahun } \\
2001-2018\end{array}$ \\
\hline $\begin{array}{l}\text { Rerata Suhu } \\
\text { Udara ( }{ }^{\circ} \text { C) }\end{array}$ & 26,6 & 26,9 \\
\hline $\begin{array}{l}\text { Rerata Jumlah } \\
\text { Curah Hujan } \\
\text { (mm) per tahun }\end{array}$ & 1876,1 & 2914,4 \\
\hline $\begin{array}{l}\text { Rerata Lama } \\
\text { Penyinaran } \\
\text { Matahari (pkl } \\
\text { 08.00 - 16.00) }\end{array}$ & 5 & 5 \\
\hline $\begin{array}{l}\text { Bulan Basah } \\
\text { Bulan Kering }\end{array}$ & 2 & 3 \\
\hline $\begin{array}{l}\text { Tipe Iklim Klasifi- } \\
\text { kasi Oldeman }\end{array}$ & E3 & D3 \\
\hline
\end{tabular}

Tabel 1 menunjukkan bahwa di Kabupaten Garut pada periode 1982- 2000 dan periode
2001-2018 mengalami peningkatan rata-rata suhu udara sebesar $0,3^{\circ} \mathrm{C}$. Selain suhu udara, rerata jumlah curah hujan pada dua periode juga telah mengalami peningkatan sebesar $947,3 \mathrm{~mm}$ per tahun. Peningkatan curah hujan yang terjadi merupakan dampak dari kenaikan suhu muka bumi, yang mengakibatkan evaporasi meningkat dan peningkatan volume air dalam pembentukan awan yang berakibat terjadinya curah hujan dengan intensitas yang lebih tinggi (Puspitasari et al., 2016). Rata-rata lama penyinaran matahari tidak mengalami perubahan dalam dua periode penyinaran matahari di Kabupaten Garut, yaitu 5 jam per hari. Pada klasifikasi tipe iklim Oldeman (1975), tipe iklim Kabupaten Garut berubah dari E3 menjadi D3. Bulan basah yang lebih banyak disebabkan adanya pengaruh dari perubahan iklim yang memicu terjadinya perubahan curah hujan dan menjadikan musim hujan lebih panjang. Selain itu, trend curah hujan dan suhu udara juga mengalami peningkatan, sedangkan trend lama penyinaran matahari mengalami penurunan (Gambar 2 dan 3).

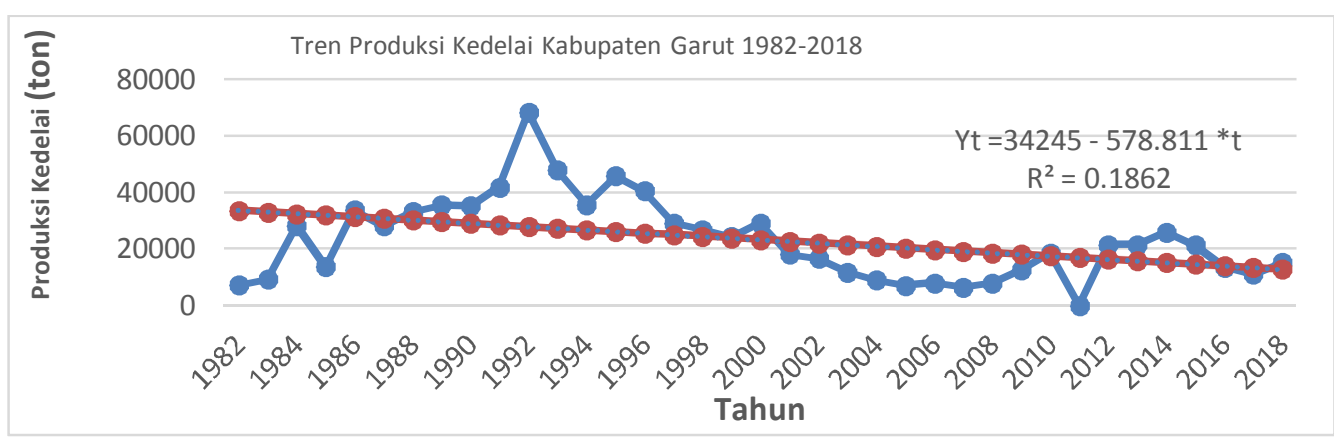

Gambar 1. Produksi kedelai kabupaten Garut.

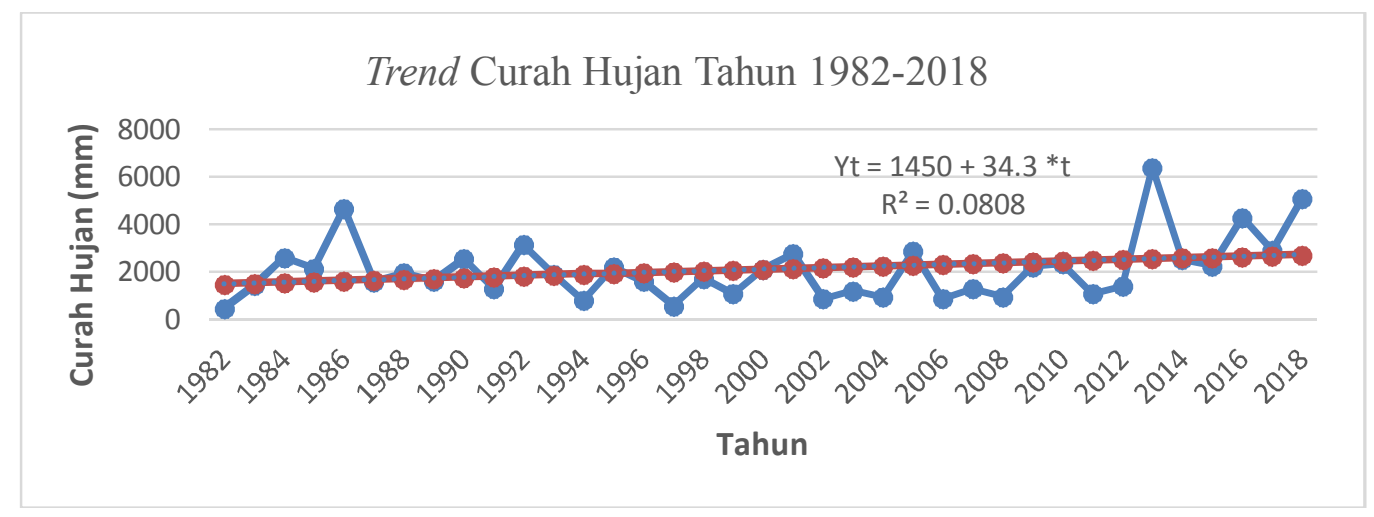


Gambar 2. Trend curah hujan tahun 1982-2018 di kabupaten Garut.

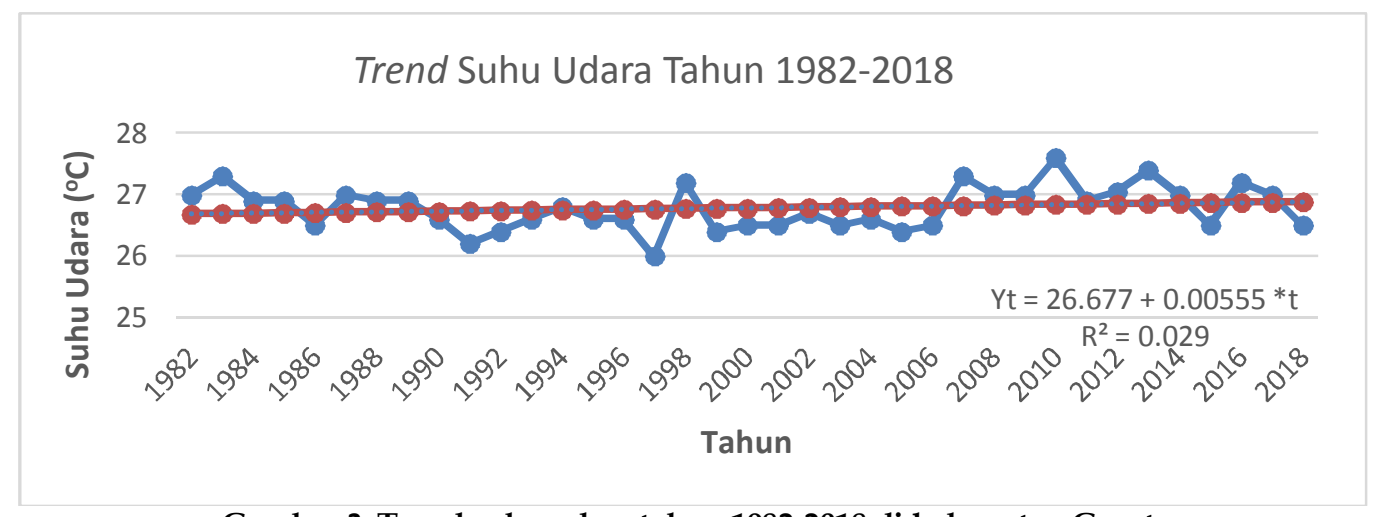

Gambar 3. Trend suhu udara tahun 1982-2018 di kabupaten Garut.

Trend curah hujan dan suhu udara yang meningkat disebabkan oleh keragaman curah hujan yang sangat tinggi yang diakibatkan oleh kenaikan aktivitas naiknya massa udara karena pemanasan global pada daerah tertentu (Visa, 2006).

Korelasi Hubungan Perubahan Iklim dengan Perubahan Produksi Kedelai di Kabupaten Garut. Produksi atau hasil suatu tanaman dipengaruhi oleh korelasi antara faktor genetik dan faktor lingkungan, seperti tanah, topografi, teknik budidaya, dan iklim. Kondisi iklim yang mengalami perubahan akan memberikan pengaruh terhadap penentuan hasil panen suatu jenis tanaman, tak terkecuali untuk tanaman kedelai. Analisis korelasi pada kedelai dilakukan untuk mengetahui besarnya korelasi antara perubahan produksi, produktivitas, dan luas tanam kedelai dengan adanya perubahan pada unsur iklim, yang meliputi curah hujan, suhu udara, dan lama penyinaran matahari. Hasil analisis korelasi antara perubahan iklim terhadap perubahan produksi, produktivitas, dan luas tanam tanaman kedelai di Kabupaten Garut dapat dilihat pada Tabel 2.

Tabel 2. Korelasi perubahan produksi kedelai dengan iklim di kabupaten Garut

\begin{tabular}{cccc}
\hline Korelasi & $\begin{array}{c}\text { Curah } \\
\text { Hujan }\end{array}$ & $\begin{array}{c}\text { Suhu } \\
\text { Udara }\end{array}$ & $\begin{array}{c}\text { Lama } \\
\text { Penyinaran }\end{array}$ \\
\hline Produksi & 0,640 * & 0,230 * & 0,231 * \\
\hline Produktivitas & 0,486 * & 0,196 * & 0,003 \\
\hline Luas Tanam & $0,530 *$ & $0,166^{*}$ & $0,240 *$ \\
\hline
\end{tabular}

Keterangan : (*) signifikan

Tabel 2 menunjukkan bahwa perubahan yang terjadi pada produksi kedelai berkorelasi signifikan terhadap perubahan curah hujan, suhu udara, dan lama penyinaran matahari. Hal ini berarti perubahan pada beberapa parameter iklim yang terjadi berpengaruh terhadap perubahan produksi kedelai. Menurut Fischer et al. (2002), adanya penurunan produksi pada tanaman pangan dipengaruhi oleh variabilitas iklim, khususnya di kawasan Asia Tenggara. Hasil korelasi juga menunjukkan positif yang berarti perubahan pada produksi kedelai memiliki hubungan searah dengan perubahan unsur iklim yaitu curah hujan, suhu udara, dan lama penyinaran matahari. Hasil analisis korelasi antara perubahan produktivitas terhadap perubahan iklim menunjukkan bahwa perubahan yang terjadi pada produktivitas kedelai berkorelasi signifikan terhadap perubahan curah hujan dan suhu udara. Hal tersebut disebabkan terjadinya pola perubahan curah hujan yang dapat menyebabkan terjadinya ancaman kekeringan ataupun banjir yang dapat mempengaruhi produktivitas kedelai (Prilyscia et al., 2018). Berbeda dengan luas tanam, dimana luas tanam kedelai memiliki hasil korelasi yang signifikan terhadap curah hujan dan lama penyinaran matahari, namun tidak signifikan dengan suhu udara, artinya suhu udara tidak terlalu berpengaruh terhadap luas tanam kedelai. Sesuai dengan kajian FAO (2005) bahwa sebesar $11 \%$ lahan pertanian di negara-negara berkembang dipengaruhi oleh perubahan dan variabilitas iklim. 
Terdapat pula analisis korelasi antara unsur iklim, yaitu curah hujan dan suhu udara, terhadap produksi dan produktivitas kedelai pada 42 kecamatan di Kabupaten Garut yang tercantum ke dalam bentuk peta (Gambar 4 dan Gambar 5). Hasil analisis korelasi pada Gambar 4 menunjukkan bahwa tingkat korelasi produksi kedelai dengan curah hujan di Kabupaten Garut didominasi oleh tingkat korelasi signifikan yang rendah dengan arah positif seperti di Kecamatan Bungbulang, Tarogong Kaler, Garut Kota, Karangpawitan, Banyuresmi, Cibatu, dan Selaawi dengan korelasi antara 0,2 hingga 0,39.Terdapat pula korelasi signifikan namun dengan arah negatif, yang berarti korelasi antara perubahan produksi kedelai dengan perubahan curah hujan memiliki hubungan berlawanan, yang berada di Kecamatan Mekarmukti, Pakenjeng, Karangtengah, Kadungora, Lim-bangan dan Talegong.

Hasil analisis korelasi pada Gambar 5 menunjukkan tingkat korelasi signifikan kuat dengan arah positif dengan nilai antara 0,6 - 0,79 yang berada di Kecamatan Caringin, Talegong, Cikelet, Tarogong Kidul, Garut Kota, Karangpawitan, Leles dan Cibatu. Hal tersebut dapat diartikan bahwa produktivitas kedelai di kecamatan-kecamatan tersebut sangat dipengaruhi oleh curah hujan dan memiliki hubungan searah, sementara di Kecamatan Sukawening hubungan antara curah hujan dan produktivitas kedelai memiliki arah yang berlawanan.

Proyeksi Produksi Kedelai Tahun 2030 di Kabupaten Garut. Proyeksi produksi kedelai merupakan upaya dalam mendapatkan gambaran produksi kedelai di masa depan, sebagai respons terhadap adanya perubahan dari faktor-faktor yang mempengaruhi produksi kedelai, yaitu perubahan iklim seperti suhu udara, curah hujan, dan lama penyinaran matahari serta perubahan dari produktivitas kedelai di Kabupaten Garut. Proyeksi produksi kedelai akan dilakukan sampai tahun 2030. Menurut Hanke et al. (2003), proyeksi merupakan suatu ketidakpastian, sehingga dilakukan dalam jangka waktu yang tidak panjang, di mana asumsi utamanya adalah ketidakpastian dalam iklim, gejolak ekonomi, dan politik. Hasil proyeksi produksi dan produktivitas kedelai di Kabupaten Garut pada sepuluh tahun kedepan tersaji pada Tabel 3.

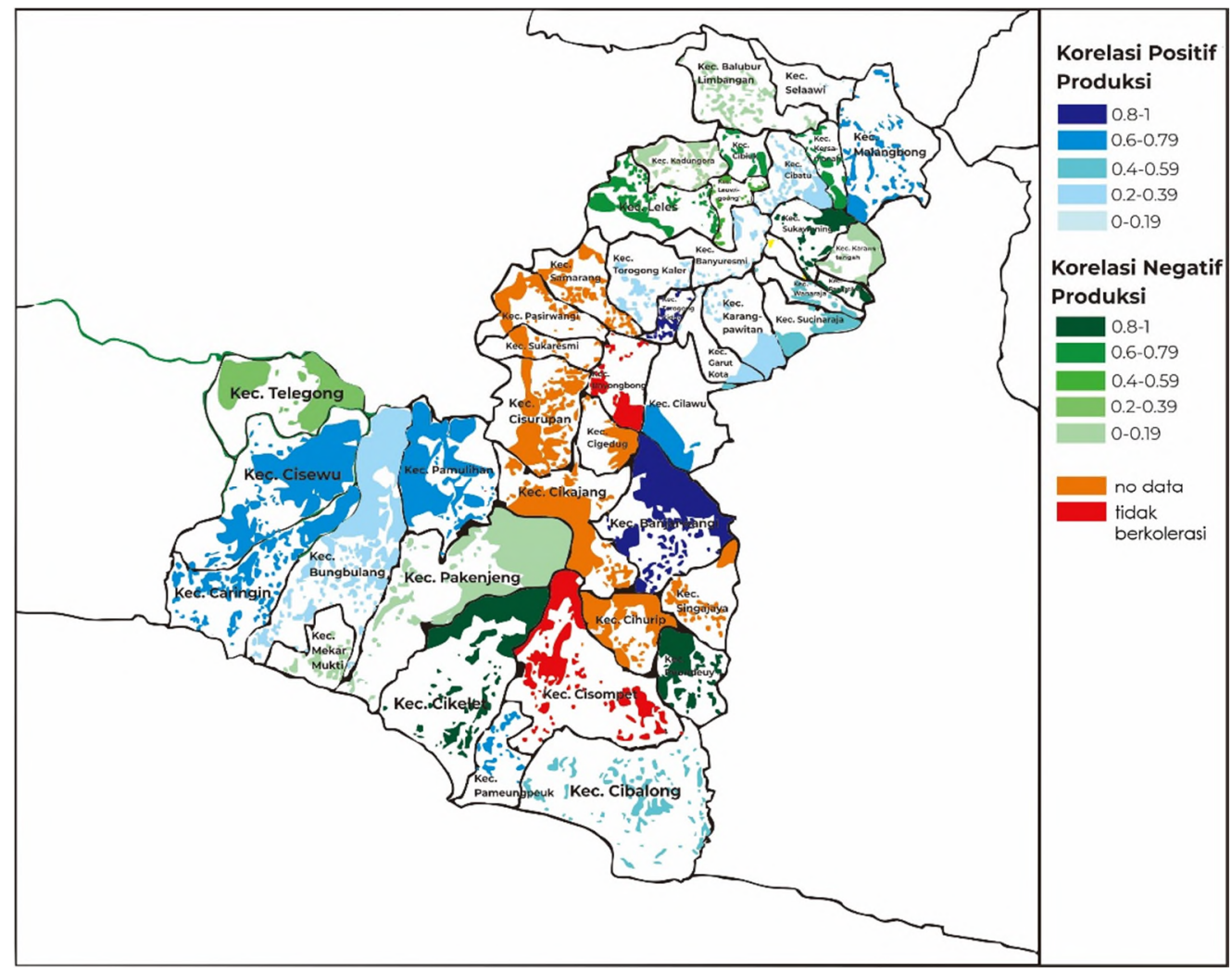

Gambar 4. Peta spasial korelasi produksi kedelai dan curah hujan di kabupaten Garut. 


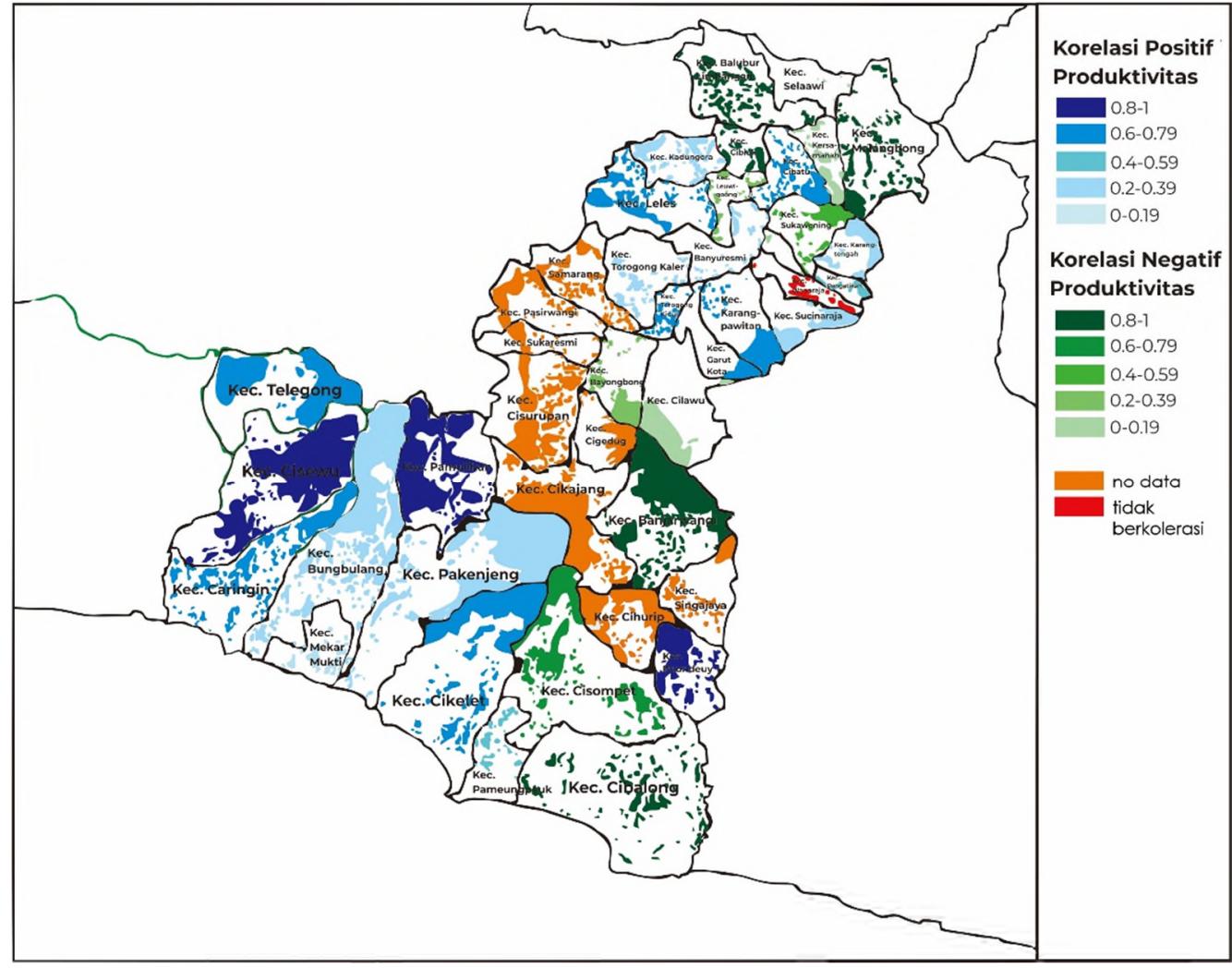

Gambar 5. Peta spasial korelasi produktivitas kedelai dan curah hujan di kabupaten Garut.

Tabel 3. Proyeksi Produksi dan Produktivitas Kedelai di Kabupaten Garut.

\begin{tabular}{ccc}
\hline Tahun & $\begin{array}{c}\text { Produksi } \\
\text { (ton) }\end{array}$ & $\begin{array}{c}\text { Produktivitas } \\
\text { (ton/ha) }\end{array}$ \\
\hline $\mathbf{2 0 1 9}$ & 25.312 & 1,53 \\
\hline $\mathbf{2 0 2 0}$ & 29.374 & 1,49 \\
\hline $\mathbf{2 0 2 1}$ & 32.222 & 1,48 \\
\hline $\mathbf{2 0 2 2}$ & 27.187 & 1,51 \\
\hline $\mathbf{2 0 2 3}$ & 29.377 & 1,50 \\
\hline $\mathbf{2 0 2 4}$ & 32.365 & 1,50 \\
\hline $\mathbf{2 0 2 5}$ & 28.215 & 1,51 \\
\hline $\mathbf{2 0 2 6}$ & 30.615 & 1,51 \\
\hline $\mathbf{2 0 2 7}$ & 31.570 & 1,51 \\
\hline $\mathbf{2 0 2 8}$ & 29.695 & 1,52 \\
\hline $\mathbf{2 0 2 9}$ & 30.904 & 1,52 \\
\hline $\mathbf{2 0 3 0}$ & 31.819 & 1,52 \\
\hline
\end{tabular}

Hasil proyeksi pada Tabel 3 menunjukkan bahwa produksi kedelai di Kabupaten Garut pada tahun 2019-2030 akan mengalami fluktuasi setiap tiga tahun sekali. Di mana pada tahun 2019 hingga tahun 2021 produksi kedelai akan mengalami peningkatan, namun kembali mengalami penurunan pada tahun 2022 dan begitu seterusnya hingga tahun 2030 . Sedangkan untuk produktivitas kedelai juga mengalami penurunan, meskipun pada tahun 2023 hingga tahun 2020 produktivitas kedelai cenderung stabil. Kondisi dimana terjadinya penurunan produksi dan peningkatan produktivitas mencerminkan bahwa kenaikan produktivitas disebabkan oleh penurunan luas panen yang lebih besar dibandingkan dengan produksinya.

Pilihan Adaptasi Strategis Tanaman Kedelai di Kabupaten Garut. Penurunan produksi kedelai di Kabupaten Garut akibat dari berbagai macam faktor perlu dicegah sehingga Kabupaten Garut tetap menjadi salah satu penghasil kedelai tertinggi di Jawa Barat. Hal yang dapat dilakukan ialah dengan melalui adaptasi strategis. Adaptasi merupakan penyesuaian diri dengan lingkungan fisik dan sosial melalui beberapa pendekatan untuk menghadapi kemungkinan timbulnya dampak negatif akibat adanya perubahan iklim (Subair et al., 2014). Upaya-upaya adaptasi perlu dilakukan untuk mempersiapkan dan mengantisipasi dampak yang mungkin akan terjadi. Segala informasi terkait adanya perubahan iklim dan bagaimana dampaknya terhadap penurunan produksi kedelai di wilayah Kabupaten Garut diperlukan dalam merekomendasikan adaptasi strategis sehingga 
penurunan lebih lanjut pada produksi kedelai dapat dicegah.

Para petani di Kabupaten Garut merupakan petani subsisten, dengan penguasaan luas lahan kurang dari 0,2 ha. Umumnya mereka telah mengetahui tentang perubahan iklim dan bagaimana dampaknya terhadap pertanian, seperti meningkatnya suhu udara maupun curah hujan yang dapat menimbulkan bencana banjir maupun kekeringan. Mereka memahami bahwa adanya perubahan iklim ini mengakibatkan perubahan maupun penurunan hasil produksi tanaman kedelai. Beberapa upaya adaptasi yang telah dilakukan oleh para petani kedelai di wilayah Kabupaten Garut adalah dengan menggunakan benih kedelai varietas Anjasmoro yang dianjurkan dari Dinas Pertanian Provinsi Jawa Barat. Upaya adaptasi juga dilakukan dengan Pengelolaan Hama Terpadu (PHT), yaitu dengan sanitasi untuk meminimalkan risiko tanaman kedelai terserang oleh organisme pengganggu tanaman. Petani juga melakukan pemeliharaan irigasi yang bermanfaat dalam meminimalisir bencana banjir dan kekeringan yang berisiko menyebabkan gagal panen. Hal tersebut dianggap baik karena pemeliharaan pola pengairan mampu menurunkan pengurangan hasil pertanian sebesar $16 \%$ (Candradijaya et al., 2014).

Terdapat pula beberapa strategi adaptasi lain yang dapat dilakukan untuk mencegah terjadinya penurunan produksi kedelai, yaitu selain dengan menggunakan varietas kedelai tahan hama dan penyakit, perlu juga melakukan penanaman kedelai yang memiliki umur genjah dan hasil produksi yang tinggi seperti varietas Dega 1 yang tahan terhadap cekaman kekeringan serta mengurangi konsumsi air dan biaya pengairan. Varietas Dega 1 mempunyai potensi hasil hingga 3,82 ton/ha dengan umur panen 69-73 hari dan tahan penyakit karat daun serta hama pengisap polong (Balitkabi, 2016). Selanjutnya, adaptasi dapat dilakukan dengan pengaturan waktu tanam dan pola tanam. Menurut Laux (2010), pengaturan waktu tanam yang tepat dapat meningkatkan produktivitas tanaman. Perlu juga membuat sumur resapan air yang berfungsi untuk menampung dan meresapkan air hujan yang jatuh di atas permukaan tanah (Bisri dan Prastya, 2009). Menurut Kusnaedi (2011) sumur resapan air berfungsi untuk pengendali banjir, konservasi air tanah, dan menekan laju erosi. Hidayati dan
Suryanto (2015) menambahkan bahwa pembuatan sumur resapan di sekitar lahan dapat mengairi lahan ketika musim kemarau tiba.

\section{Kesimpulan}

Wilayah Kabupaten Garut telah mengalami perubahan iklim dengan indikasi adanya trend peningkatan suhu udara rata-rata $0,3^{\circ} \mathrm{C}$ dan trend peningkatan curah hujan sebesar 77 $\mathrm{mm} /$ tahun, tetapi lama penyinaran matahari terjadi trend penurunan. Terdapat hubungan korelasi signifikan antara perubahan iklim dengan produksi, produktivitas, dan luas tanam kedelai di Kabupaten Garut. Telah dilakukan beberapa pilihan adaptasi strategis oleh petani Kabupaten Garut untuk menghadapi risiko penurunan produksi tanaman kedelai akibat perubahan iklim.

\section{Daftar Pustaka}

Apriyana Y, Susanti E, Suciantini, Ramadhani F, Surmaini E. 2016. Analisis Dampak Perubahan Iklim terhadap Produksi Tanaman Pangan pada Lahan Kering dan Rancang Bangun Sistem Informasinya. J. Informatika Pertanian. 25 (1): 69- 80.

Adinasa, L., dan Ronnie, S.N. 2015. Faktor Yang Mempengaruhi Luas Penanaman Kedelai di Kabupaten Garut Privinsi Jawa Barat. Fakultas Pertanian. Universitas Padjadjaran.

Badan Pusat Statistik. 2015. Jawa Barat Dalam Angka 2015.

Bisri, Mohammad dan Prastya. 2009. Imbuhan air tanah buatan untuk mereduksi genangan (Studi Kasus di Kecamatan Batu Kota Batu. Jurnal Rekayasa Sipil. 3(1).

Carolina, R.A., S. Mulatsih., dan L. Anggraeni. 2016. Analisis Volatilitas Harga dan IntegrasiPasar Kedelai Indonesia dengan Pasar Kedelai Dunia. Jurnal Agro Ekonomi,34(1): 46-48.

Candradijaya, A., Kusmana., dan Y. Syaukat. 2014. Pemanfaatan Model Proyeksi Iklim dan Simulsai Tanaman Dalam Penguatan Adaptasi Sistem Pertanian Padi Terhadap Penuruna Produktivitas Akibat Perubahan Iklim : Studi Kasus di Kabupaten Garut, 
Jawa Barat. Pusat Kerjasama Luar Negeri Kementerian Pertanian. Jakarta.

Dinas Perindustrian Kabupaten Garut. 2012. Industri di Kabupaten Garut. Garut.

Dinas Tanaman Pangan danHortikultura Kabupaten Garut. 2018. Produksi, areal panen, produktivitas kedelai di Kabupaten Garut. Garut

Fischer, G., Shah, M., Velthuizen, H.V. 2002. Climate change and agricultural vulnerability. IIASA. Luxemburg: Austria.

Food and Agriculture Organization. 2005. Impact of climate change and diseases on food security and proverty reduction. Spesial Event Background Document for The 31st Session of Committee on World Food Security. Rome 23-26 May 2005.

Hadi, A. 2013. Analisis Produksi dan Konsumsi Kedelai Domestik Dalam Rangka Mencapai Swasembada Kedelai di Indonesia. Departemen Ekonomi Sumberdaya dan Lingkungan, Institut Pertanian Bogor.

Handoko, I., Y. Sugiarto, Y. Syaukat. 2008. Keterkaitan Perubahan Iklim dan Produksi Pangan Strategis: Telaah Kebijakan Independen dalam Bidang Perdagangan dan Pembangunan. Seameo Biotrop. Bogor.

Hanke, J.E., Wichern, D.W., Reitsch, A.G. 2003. Peramalan Bisnis. Jakarta. PT. Prenhallindo.

Hidayati, I., dan Suryanto. 2015. Pengaruh Perubahan Iklim Terhadap Produksi Pertanian dan Strategi Adaptasi Pada Lahan Rawa Kekeringan. Fakultas Ekonomi dan Bsinis, Universitas Sebelas Maret.

Kusnaedi, 2011. Sumur Resapan untuk Pemukiman, Perkotaan, dan Pedesaan. Jakarta : Penebar Swadaya.

Laux, P., G. Jäckel, R.T. Munang and H. Kunstmann. 2010. Impact of climate change on agricultural productivity under rainfed conditions in Cameroon - A method to improve attainable crop yields by planting date adaptations. Agric. Forest Meteorol. 150: 1258-1271.

Malian, A. H. 2004. Kebijakan Perdagangan Internasional Komoditas Pertanian di Indonesia. Analisis Kebijakan Perdagangan, Vol. 2 No. 2, Juni 2004. Bogor: Pusat Analisis Sosial Ekonomi dan Kebijakan Pertanian.

Mantom, M.J., P.M. Della-Marta, M.R. Haylock, K.J. Hennessy, N. Nicholls, L.E. Chambers, D.A. Collins, and G. Daw. 2001. Trends in extreme daily rainfall and temperature in Southeast Asia and the South Pacific; 19611998. J. Climatol. 21: 269-284.

Oldeman, L.R., 1975. Agroclimatic map of Java \& Madura. Contr. of Centra Res. Inst. for Food Crops 16/76. Bogor.

Prilyscia, A., Sutarno., dan Rahayu. 2018. Hubungan Alih Fungsi lahan dan Perubahan Iklim Terhadap Hasil Komoditas Pertanian di Jumantono. Universitas Sebelas Maret Surakarta.

Puspitasari, P., dan O. Surendra. 2016. Analisis Trend Perubahan Suhu Udara Minimum dan Maksimum Serta Curah Hujan Sebagai Akibat Perubahan Iklim di Provinsi. Balai Besar Meteorologi Klimatologi da Geofisika Wilayah V Jayapura.

Putra, Eka T. S., Didik Indradewa. 2011. Perubahan Iklim dan Ketahanan Pangan Nasional. Artikel Kerjasama Panitia Lustrum13 Fakultas Pertanian UGM dengan Koran Kedaulatan Rakyat Edisi 2.

Runtunuwu, E. and A. Kondoh. 2008. Assessing global climate variability and change under coldest and warmest periods at different latitudinal regions. Indones. J. Agric. Sci. 9(1): 7 $\square 18$.

Subair, L.M. Kalopaking, S. Adiwibowo, dan M. Bambang. 2014. Adaptasi Perubahan Iklim Komunitas Desa : Studi Kasus di Kawasan Pesisir Utara Pulau Ambon. Jakarta 